\title{
Evaluating Branching and Sales Point Banking as Market Strategies to Raising Performance of Banks in Nigeria
}

\author{
Kolapo, Funso. T. (Ph.D) \\ Ajayi, Omobola. M. (Ph.D) \\ Adegoke, Asimiyu. K. (M. sc) \\ Adeleke, Kareem. O (Ph. D) \\ 1,2, Ekiti State University, Department of Finance and Department of Business Administration \\ ${ }^{3}$ Achievers University, Owo, Ondo State, ${ }^{4}$ Federal Polytechnic, Ado-Ekiti
}

\begin{abstract}
A prerequisite in a competitive market environment is a result-oriented market strategies that are customer service oriented. Good service delivery channels have been considered as relevant in this regard. This study evaluates the effect of spread of bank branches and utilization of e-payment system in form of sales point banking on return on equity of banks. Banks in Nigeria were sampled and both primary and secondary data were used. Findings from Panel regression model estimate show a strong support for more branch establishment as a relevant market channel to increase performance of banks. Sales point banking do not have significant effect on return on equity. The findings suggest the need for banks to target the geographical spread of customers and make adequate provision for more bank branches. The expected advantage of proximity is duly linked to increasing performance of banks in Nigeria.
\end{abstract}

Keywords: Market Strategy, Bank Branch, Sales Point Banking, Return on Equity

DOI: $10.7176 / \mathrm{EJBM} / 13-3-11$

Publication date: January $31^{\text {st }} 2021$

\section{Introduction}

A wide range of financial products and services are offered by banks to numerous individual and corporate customers. Some of the services include deposit taking, paying cash, granting loans,selling foreign exchange, transferring funds, cheque clearing,guarantorship and business investment advice offered to appreciable number of customers(Leye-Isola, 2007). Meanwhile, other bank financial services which cover credit cards transactions need to be brought to the attention of potential users, who are required to be persuaded to embrace them (Abolaji, 2009). In the ever growing competitive business environment, most of the services offered by banks are also being offered by non-bank financial intermediaries and informal financial service operators (Nwankwo, 1985). Banks do not only face competition with each other but are also required to deal with other related challenges from related institutions in the financial market (Ojo, 2012). In order to be successful in this type of environment, banks need a good understanding of the marketing strategies which may aid improvement in the level of banks performance. A good marketing strategy requires an organization to be market-focused by building the products or services that are acceptable to the customers. A number of market strategies needed to attract customers and thereby raise bank performance level include establishment of market presence through branching and electronic based transactions in form of sales point banking (Kolapo, 2018).

Prior to the technological springs in the global banking system, branch presence remained the only viable channel of service delivery to customers. Thereafter, the earlier manual way of banking operation became automated, thereby saving a lot of business time and effort (Uppal, 2011). In today's business environment, customers can choose between bank branches and other form of service delivery channels such as sales point banking to transact businesses. Roth and Menor (2003) noted that service delivery systems can significantly affect firms' operations strategy and other related business processes that have direct interaction with the customers. In the banking sector, the performance of the service delivery channel reflects the effective linkage between the banks' product and service and the customers. The extent to which banks can utilize the business opportunity offered by branching and sales point banking may determine the rate of growth in their performance indices. Moreover, the increasing competition in the financial sector requires operational understanding of customer needs and the relevant strategic market channels that can meet their transactional objectives. The non-impressive bank performance trend as reflected in the flow of their return to equity justify the need to embrace business channels that aid the coping strategies devised to survive competition. For example, the commercial banks performance outlook has shown unstable trend up till 2017. In 2012, the performance outlook of Nigerian banks was relatively high at a rate of 3.269. But, from the following period in 2013, sharp decline was observed and the rate fell to 2.051. The declining trend continued in 2014 when the rate fell to 1.753 and 1.639 in 2015 before a relative increase was observed in the year 2016 (Table 1) (CBN, 2017). The suggestion from the performance trend of the banks is that banks need to shift focus and embrace marketing practices that will help in identifying consumer needs while providing acceptable services for better performance. 
Table 1: Performance outlook of banks in Nigeria

\begin{tabular}{|c|c|}
\hline Period & ROA \\
\hline 2012 & 3.269 \\
\hline 2013 & 2.051 \\
\hline 2014 & 1.753 \\
\hline 2015 & 1.639 \\
\hline 2016 & 2.838 \\
\hline
\end{tabular}

Source: CBN statistical report, 2017

Existing studies on assessment of effect of bank branches on performance of banks is limited while studies on sales point banking focused largely on the factors influencing adoption from banking technological point of view. Omotayo and Dahunsi (2015) while focusing only on adoption also agreed to the non-applicability of their study to the entire banking scape in Nigeria due to several limitations of their study. Adelowotan and Oshadare (2016) related growth in bank branches to increase in size of the banks as a measure of performance. However, using size as a measure of bank performance growth is flawed as size does not necessarily imply growth in financial performance which is core to the existence of a bank (Kolapo, Ajayi\&aluko, 2016). This study attempts to view the need for increasing performance of banks through marketing strategy that addresses delivery channels such as branching and sales point banking distributions.

\subsection{Literature Review \\ 2.1 Concept of Marketing}

Financial institutions view marketing activities in a strategic light. Marketing therefore, plays a crucial role in the formulation of corporate strategies (Amaoko and Dartey-Baah, 2012). It recognizes marketing as very important because marketing decisions are taken at the very top management level. Kotler and Keller (2006) view marketing concept as the key to achieving corporate goals which involves determining the needs and satisfaction more effectively and efficiently than competitors. They also considered marketing theory and practice as being justified in the belief that individual customer make use of a product or service due to need, or perception of a particular benefit (Kotler \& Keller, 2006). Marketing efforts and know-how are instrumental in commercializing ideas and inventions successfully. Therefore, it could be disastrous for organizations to ignore the importance of marketing.

Kotler (1999) opines that, in the future, marketing has the main responsibility for achieving profitable revenue growth for the company. Cost-efficiency conduct of business no longer provide long-term competitive advantage for companies today, whereas marketing, when appropriately conducted, guarantees long-term competitive advantage especially in the field of strategic marketing. Some past studies on the influence of strategic marketing on performance (Hooley, Greenley, Fahy\&Cadogan, 2001) indicated that marketing capabilities and assets possess the potential to be important sources of competitive advantage for companies. In addition, marketing with strong market orientation seems to be increasingly important for firms.

Therefore, it is pertinent that firms should start embracing the principles of strategic marketing (Kimutai, 2015).

\subsection{Branching}

Location of a banks' brand in different geographical points in a well-defined area is referred to as branching of banks. There is an indication that depositors put serious consideration into geographic contact and branch distribution when taking decision on a depository institution (Abor, 2003). A study by Hannan and Prager (2004) concluded that large and multi-market banks provide lower deposit rates to customers than smaller, one-market banks. Also, the rates provided by a single market bank are turned down when the market share of big and multimarket banks surges. This study places emphasis on the influence of the spread of wide-market financial business on market competition in restrained banking environment. Intuitively, large and multi-market financial banks are able to access a less costly widespread funding foundation and are therefore least expected to contend for retail deposits as a source of finances. A well spread bank service branches involves important costs which banks must cover through various revenues that are generated by the marketing systems (Orlow, et al. 1996). With several branches of a bank serving the customers, there is a simulated division of labour among different branches of the banks and the associated positive impact on performance among branches. The customer travel distance to banks main business office is cut down while providing more time for other customers' activities. Relieving the business pressure on the main financial base enables banks to perform diverse financial transactions more efficiently while attracting high-end customers by providing more personalized services. Hirtle, (2007) found increasing performance of branch network to be highly consistent with bank beliefs that branch will continue to serve as an effective channel for generating revenues in spite of the associated costs. Xue, Hitt and Chen (2009) also found complementary association between investment in branches and performance of banks. 


\subsection{Point of Sales transaction}

Point of sales transaction is a form of electronic payment systems designed to boost service delivery to customers while increasing fund mobilization drives for banks. Its introduction came as a result of the Central Bank of Nigeria $(\mathrm{CBN})$ strategic plan on electronic payment system with a view to ensuring that a larger proportion of currency in circulation is captured within the banking system. This is expected to enhance the efficacy of monetary policy operations and economic stabilization measures put in place by the financial regulatory bodies. This according to Adeoti and Oshotimehin, (2012) ensured drastic reduction in the volume of cash transactions and the flow of cash in the Nigerian economy. The point of sale banking and other electronic systems provide a better audit trail than transactions which involve physical cash thereby reducing the amount of currency in the circulation. Omotayo and Dahunsi (2015) explained that point of sale transaction is one of the electronic payment systems to aid the course of cashless policy in the country. As an electronic payment device, it enables customers to carry out business transactions with electronic cards without physical cash. A projection of an upward increase in the point of transaction which rose to about 350,000 in 2014 from 120,191 in 2013, reflecting growing acceptance of the banking model and electronic card payments. An increase of about $183 \%$ compound annual growth rate is expected suggesting significant relevance of the transaction mode to business preference of consumers (Omotayo and Dahunsi, 2015)

\subsection{Methodology}

Quantitative research design was adopted for the study. Data were collected from primary and secondary sources. The secondary data cover the period between 2005 and 2016 and were obtained from Annual reports and statement of accounts of the banks. The secondary data, covering eight (8) commercial banks, were obtained on return on equity as a proxy for performance, numbers of bank branches and volume of point of sales transactions over the period. The primary data for the study was obtained through structured questionnaire to gauge the advantages obtained by the banks with increasing number of branches and point of sales transactions. To achieve this, 1200 bank customers were randomly sampled. Descriptive statistics and panel regression techniques were used to analyze the data collected. The explicit models for Pooled, Fixed and Random effects models of the panel regression are presented below;

\subsection{Pooled Panel Regression Models}

The Pooled panel model assumes that any heterogeneity across firms has been averaged out. Thus the pooled estimation is given as

$$
R O E_{i t}=\beta_{0}+\beta_{1} B R C_{i t}+\beta_{2} P O S_{i t}+\beta_{3} S I Z_{i t}+\varepsilon_{i t}
$$

\subsection{Fixed Panel Regression Model}

The fixed effect model assumes that individual heterogeneity is captured by the intercept term. This means every firm was assigned its intercept ${ }_{i}$ while the slope coefficients are the same, and the heterogeneity is associated with the regressors on the right hand side. In the model, a dummy is assigned to every individual bank.

$$
R O E_{i t}=\beta_{0}+\beta_{1} B R C_{i t}+\beta_{2} P_{O S}+\beta_{3} S I Z_{i t}+\sum_{i=1}^{15} \alpha_{i} i d u m+\varepsilon_{i t}
$$

Where $\alpha_{i}$ idum is a dummy variable and $a_{i}$ is an unobserved effect

\subsection{Random Effect Model}

The random effect model assumes that the individual bank heterogeneity is uncorrelated with (or, more strongly, statistically independent of) all the observed variables. Going by this assumption the following model is specified;

$$
R O E_{i t}=\beta_{0}+\beta_{0}+\beta_{1} B R C_{i t}+\beta_{2} P O S_{i t}+\beta_{3} S I Z_{i t}+V_{i t}
$$

Where

$V_{i t}=\alpha_{i}+\varepsilon_{i t}$ is often called the composite error.

$\mathrm{ROE}=$ Return on equity

$\mathrm{BRC}=$ number of bank branches

$\mathrm{MBK}=$ Volume of point of sales transaction

$\mathrm{SIZ}=$ Bank size

\section{Results}

\subsection{Descriptive statistics of the data}

Results in Table 1 show the descriptive statistics of the data to describe the relevance of branching to the banks marketing efforts. The sample respondents agreed (4.21) that branch network of banks influences new customers. 
They also agreed (4.76) that more bank presence reduces customer travel distance for bank transactions and thus offers ample time for customer's productive activities. They also agreed (4.44) that branching offers convenience of many possible points of contact with the bank and that branch is an effective channel for generating retail banking revenues (4.81). The respondents are undecided on whether the customers select their bank primarily due to its location.

Table 1: Relevance of branching to bank performance

\begin{tabular}{|l|l|l|}
\hline & Mean & $\begin{array}{l}\text { Standard } \\
\text { deviation }\end{array}$ \\
\hline Branching influences new customers & 4.21 & 1.542 \\
\hline $\begin{array}{l}\text { More bank presence curtails customer travel distance for financial transaction and } \\
\text { thus offers more time for customers' productive activities }\end{array}$ & 4.76 & 1.226 \\
\hline Branching offers convenience of many possible points of contact with the bank & 4.44 & 1.303 \\
\hline Customers select their bank primarily due to its location & 3.41 & 1.328 \\
\hline Branch is an effective channel for generating retail banking revenues & 4.81 & 1.241 \\
\hline
\end{tabular}

\section{Source: Data Analysis, 2018}

Key: 5 = Strongly Agreed, $4=$ Agreed, $3=$ Not true, 2 = disagree, $1=$ strongly disagree

The relevance of point of sale transaction to marketing strategies of the banks and performance is descriptively assessed based on the response of the respondents (Table 2). The respondents strongly agreed (Mean $=4.62$ ) that point of sale transaction aid the cashless policy of the banking sector and enhanced (3.97) the fund mobilization strategies of the banks. Furthermore, there is an agreement (4.05) of the respondents on the relevance of point of sale transaction to raising bank revenues thereby increasing performance of the banks. The banks respondents also agreed (3.77) that banking awareness is facilitated through point of sale business.

Table 2: Relevance of Point of Sale transactions to bank performance

\begin{tabular}{|l|l|l|}
\hline & Mean & $\begin{array}{l}\text { Standard } \\
\text { deviation }\end{array}$ \\
\hline Point of sales banking aid the cashless policy of the sector & 4.62 & 1.09 \\
\hline Funds mobilization strategy is enhanced with the use of point of sale banking & 3.97 & 1.03 \\
\hline $\begin{array}{l}\text { Bank revenue are increased through transactional charges enjoyed from POS } \\
\text { transactions }\end{array}$ & 4.05 & 1.37 \\
\hline More customers are attracted to the banks through POS business & 3.42 & 1.23 \\
\hline Banking awareness are facilitated through point of sale business & 3.77 & 1.05 \\
\hline
\end{tabular}

Source: Data Analysis, 2018

Key: 5 = Strongly Agreed, 4 = Agreed, 3 = Not true, 2 = disagree, 1= strongly disagree

\subsection{Findings from Secondary Data Analysis}

Table 3 highlights the usage of service delivery channels- branch banking system and point of sale terminal and return on equity (ROE). The average value of return on equity (ROE) of the banking firms was $14.93 \%$. The bank with the least ROE had $0.40 \%$, while the bank with most ROE over the sample period had ROE of about $30.00 \%$. The standard deviation of the ROE was relatively low, suggesting stability of the banks' return on equity over the study period. Theaverage value of POS services over the period was $\$ 127.269$ billion, with a minimum of $\$ 11.03$ billion and a maximum of $\$ 315.01$ billion. However, the standard deviation value of $\$ 128.74$ for POS transaction suggests the sales point banking as a market strategy is not a stable transactional channel. The bank with the least number of branches in the study area has 96 while the maximum number available is 242 . The average number of branch per bank in the study area is 151 branches. 
Table 3: Description of study variables

\begin{tabular}{|l|c|c|c|}
\hline & ROE & POS (Nb) & Branching \\
\hline Mean & 14.931 & 127.269 & 150.500 \\
\hline Median & 17.600 & 48.010 & 146.500 \\
\hline Maximum & 30.000 & 315.010 & 242.000 \\
\hline Minimum & 0.400 & 11.030 & 96.000 \\
\hline Std. Dev. & 7.805 & 128.747 & 48.210 \\
\hline Skewness & -0.033 & 0.595 & 0.549 \\
\hline Kurtosis & 2.212 & 1.592 & 2.218 \\
\hline Jarque-Bera & 0.9115 & 4.952 & 4.238 \\
\hline Probability & 0.634 & 0.084 & 8420 \\
\hline Sum & 522.6000 & 4454.400 & 127834.0 \\
\hline Sum Sq. Dev. & 2071.475 & 563580.3 & \\
\hline
\end{tabular}

Source: Data Analysis, 2018

\subsection{The Hausman Test of the Study Variables}

The decision on whether to use fixed or random effect for the estimation of the model was reached by conducting Hausman test. The result presented in Table 4 indicates that random effect is appropriate for the estimation of the model to study service delivery channels and bank performance after failing to reject the null hypothesis of random effect. The model was estimated using random effect because the result of the Hausman test showed a p-value of 0.79 that is more than $5 \%$.

Table 4: Correlated Random Effects - Hausman Test

\begin{tabular}{llccc} 
Test Summary & Chi -Sq. Statistic & Chi -Sq. d.f. & Prob. \\
\hline \hline Cross -sectionra & ndom & 1.03661 & 3 & 0.7924 \\
\hline \hline
\end{tabular}

Source: Data Analysis, 2018

\subsection{The Estimated Model}

The estimated model of effect of branching and sales point banking on bank performance is presented in Table 5 . The results show that parameter estimate of branching as a bank marketing strategy exerts a positive and significant influence on performance of banks $(\beta=0.675, \mathrm{P}<0.05)$. The result indicates that spread of bank branches to different locations has a strong marketing effect that results in increase in banks' return on equity. Increase in bank branches is expected to move banks' products and services closer to customers. It is expected that proximity of service to customers would bridge distance barrier to banking most especially in areas with insufficient number of banks/bank branches and as well provide physical presence to a number of customers. However, point of sale transactions, though positive, has no significant effect as a marketing strategy for the banks $(\beta=0.152, \mathrm{P}>0.05)$. The results suggest that effort at raising performance of banks through various marketing strategies should be limited to service delivery channels other than sales point banking. The result finds a positive and significant effect of size on return of equity of banks. This shows that the bigger the size of the bank, the better the performance level of the banks with their marketing strategies. 
Table 5: Panel regression estimates of the model.

\begin{tabular}{|c|c|c|c|c|c|c|}
\hline & \multicolumn{3}{|c|}{ Fixed effect } & \multicolumn{3}{|l|}{ Random Effect } \\
\hline & Coeff & Std. error & t-stat & Coeff & Std. error & t-stat \\
\hline $\mathrm{C}$ & 3.2592 & 0.657 & $4.962 * *$ & 3.663 & 0.448 & $8.164 * * *$ \\
\hline Branching & 0.0112 & 0.007 & $1.692 *$ & 0.675 & 0.098 & $6.852 * * *$ \\
\hline POS & 0.342 & 0.213 & 1.606 & 0.152 & 0.124 & 1.222 \\
\hline Size & 0.142 & 0.101 & 1.406 & 0.388 & 0.056 & $6.928 * *$ \\
\hline R-squared & 0.637 & & & 0.796 & & \\
\hline Adjusted R-squared & 0.625 & & & 0.755 & & \\
\hline Log likelihood & -173.249 & & & & & \\
\hline F-statistics & 19.546 & & & 54.429 & & \\
\hline Prob(F-statistic) & 0.0000 & & & 0.0000 & & \\
\hline Hausman & & & & $1.037(0.7924)$ & & \\
\hline
\end{tabular}

Source: Data Analysis, 2018

\section{Conclusions}

Banks employ different marketing strategies to boost their performance level in a competitive market environment. Part of that strategies is utilization of service delivery channels such as establishment of more branches to different locations and target market as well as distribution of point of sales machines to numerous market points including supermarket, shops, big stores and various business outlet with a view to mobilizing funds from different locations and as well accrue more revenue through charges to customers using those services. It is expected that those strategies would lead to increase in customer patronage and competitive edge over market rivals. The findings of this study highlight the relevance of market strategies that focus on branching and sales point banking to performance objective of the banks. The results show strong support for establishment of more branches at different locations as a good market strategy to raise performance. There is no empirical support for significant contribution of point of sales, as a competitive strategy for better performance of the banks.

\section{References}

Abolaji A. (2009). Marketing of financial services. Lagos: Central Bank of Nigeria Press.

Abor, J. (2003). Technological innovations and banking in Ghana: An evaluation of customers 'perception. Legon: University of Ghana.

Adelowotan, M. O,\&Oshadare, S.A (2016). Branch network growth and banks' performance in Nigeria (19812013). Research Journal of Finance and Accounting 7(19), 1-7.

Adeoti, O. O., \&Oshotimehin, K. O. (2012). Adoption of point of sale terminals in Nigeria: Assessment of consumers' level of satisfaction. Research Journal of Finance and Accounting, 3(1), 1-5.

Amaoko, G. K., \&Dartey-Baah, K. (2012). An analysis of the impact of strategic marketing on profitability of rural banks: A case study of Dangme Bank. International Journal ofMarketing Studies, 4(2), 150-156.

Hannan, T. H., \&Prager, R.A. (2004). The competitive implications of multimarket bank branching.Journal of Banking \& Finance, 28, 1889-1914

Hirtle, B. (2007). The role of network size on bank branch performance.Journal of Banking and Finance,31(12), $3782-3805$.

Hooley, G., Greenley, G., Fahy, J., \&Cadogan, J. (2001). Market-focused resources, competitive positioning and firm performance. Journal of Marketing Management, 17(5-6), 503-520.

Leye-Isola, A. T. (2009). Bank services in Nigeria financial industry: A case study of customer's preference for banking services in Lagos and Abuja(Unpublished MBA Thesis). University of Nigeria, Enugu, Nigeria.

Kimutai, J. J. (2015). Influence of strategic marketing practices on performance of firms in the flower industry in Kenya(M.Sc. Thesis). University of Nairobi, Kenya.

Kolapo, F. T., Ajayi, L. B.,\&Aluko, O. A.(2016). How is size related to profitability? Post-consolidation evidence from selected banks in Nigeria. International Journal of Finance \& Banking Studies 5(4) 30-38.

Kolapo, F. T. (2018). Effects of strategic marketing practices on the performance of deposit money banks in Nigeria(Ph.D. Thesis).Ekiti State University, Ado Ekiti, Nigeria.

Kotler, P. (1999). Marketing management (Millennium ed.). New Jersey: Upper Saddle River, Prentice-Hall.

Kotler, P.,\& Keller, K.L. (2006). Marketing management. Delhi: Prentice Hall of India Private Limited.

Ojo, O. M. (2012).Marketing strategies and bank performance in Nigeria: A post consolidation analysis. Research Journal of Finance and Accounting, 3(5): 93-102

Omotayo, F.,\&Dahunsi, O. (2015). Factors affecting adoption of point of sale terminals by businessorganisations 
in Nigeria.International Journal of Academic Research in Business and Social Sciences, 5 (10): 115-136

Orlow, D. K., Radecki, L. J.,\&Wenninger, J. (1996). Ongoing restructuring of retail banking.Federal reserve bank of new York research paper, 9634.

Roth, A.V.,\&Menor, L.J. (2003). Insights into service operations management: A research agenda.Production \& Operations Management, 12(2), 145-164.

Uppal, R. K. (2011). E-delivery channels in banks-A fresh outlook.Journal of Arts, Science \& Commerce II(1).

Xue, M. Hitt, L. M., and Chen, P. Y. (2009).The determinants and outcomes of internet banking adoption, working paper. 